\title{
İntravenöz Glikoz İnfüzyonu Hipotalamik Ventromediyal Nükleusta Katekolaminleri Etkiler mi?
}

\section{Does Intravenous Glucose Infusion Affect Catecholamines in Hypothalamic Ventromedial Nucleus?}

\author{
Hatice Solak ${ }^{1}$, Zülfikare Işık Solak Görmüş ${ }^{1}$, Raviye Özen Koca ${ }^{1}$, Selim Kutlu ${ }^{1}$
}

${ }^{1}$ Necmettin Erbakan Üniversitesi, Meram Tıp Fakültesi, Fizyoloji Anabilim Dalı, Konya, Türkiye

Yazışma Adresi: Hatice Solak, Necmettin Erbakan Üniversitesi, Meram Tıp Fakültesi, Fizyoloji Anabilim Dalı, Konya, Türkiye e-posta: hhaticesolak@gmail.com

Geliş Tarihi/Received: 04 Haziran 2021 Kabul Tarihi/Accepted: 07 Ekim 2021

\begin{abstract}
Öz
Amaç: İntravenöz glikoz infüzyonunun ventromediyal nükleusta (VMN), dopamin ve metaboliti dihidroksifenilasetik asit, norepinefrin ve metaboliti dihidroksifenil glikol düzeylerine etkilerinin beyin mikrodiyaliz yöntemiyle araştırılması amaçlanmıştır

Gereçler ve Yöntem: Deneylerde normal beslenen 2 grup ve 24 saat besin alımı kısıtlanan 2 grup (serum fizyolojik ve glikoz uygulanan) yetişkin erkek Wistar albino sıçan kullanıldı. Mikrodiyaliz örnekleri 20'şer dakikalık sürelerde toplandı. Illk örnekler kontrol olarak kaydedildikten sonra, kontrol gruplarına serum fizyolojik, glikoz gruplarına da \%50'lik glikoz çözeltisi $1.4 \mathrm{ml} / \mathrm{kg}$ dozunda intravenöz yolla uygulandı. Tok ve aç hayvanlarda serum fizyolojik ve glikoz uygulamasından sonraki 40 dakika boyunca örnekler toplanıp HPLC-ECD sisteminde analiz edildi. Değerler, uygulama öncesi kontrolleriyle normalize edilip tek yönlü varyans analizi kullanılarak istatistiksel olarak değerlendirildi.

Bulgular: Dopamin konsantrasyonları fizyolojik salin uygulanan aç ve tok hayvanlarda ve glikoz uygulanan aç hayvan grubunda değişmezken, glikoz uygulanan tok grupta istatistiksel olarak anlamlı olmayan bir artış gözlendi. DOPAC konsantrasyonları glikoz uygulanan tok grupta kontrolle karşılaştırıldığında istatistiksel olarak anlamlı bir artış gösterdi $(p=0,004)$

Sonuç: Çalışmanın bulguları, hipotalamik VMN'deki dopaminerjik nörotransmisyonun kan glikoz düzeyiyle değişebileceğini göstermektedir. Besin alımını takiben ortaya çıkan hiperglisemi, VMN'de dopaminerjik nörotransmitter konsantrasyonunu artırarak tokluk duygusunun oluşmasına katkı yapabilir.
\end{abstract}

Anahtar Kelimeler: Ventromediyal nükleus, dopamin, norepinefrin, HPLC, mikrodiyaliz.

\section{Abstract}

Aim: We aimed to investigate the effects of intravenous glucose infusion in dopamine and its metabolite dihydroxyphenylacetic acid, norepinephrine and its metabolite dihydroxyphenylglycol levels in ventromedial nucleus (VMN) by brain microdialysis method.

Materials and Methods: 2 groups of normally fed (saline and glucose administered) and 2 groups of 24 hours food restricted (saline and glucose administered) male adult Wistar albino rats were used. Microdialysis samples were collected at 20-minute intervals. After recording the first samples, $1.4 \mathrm{ml} / \mathrm{kg} 50 \%$ glucose solution and $0.9 \%$ saline were infused via tail vein. Then, other microdialysis samples were collected for 40 minutes from satiated and fasted rats. All microdialysis samples were analyzed by HPLC-ECD system. All values were normalised with controls before application and statistically analysed by SPSS 20.0 .

Results: While dopamine concentrations didn't change in physiological saline administered fasted and satiated animals and glucose-administered fasted animals, a statistically insignificant increase was noticed in glucose-administered satiated groups. DOPAC concentrations showed a statistically significant increase in satiated glucose group compared to control group about DOPAC concentrations $(p=0.004)$.

Conclusion: Dopaminergic neurotransmission in VMN may vary with blood glucose level. Hyperglycemia following food intake may contribute to the feeling of satiety by increasing dopaminergic neurotransmitter concentration in VMN.

Key words: Ventromedial nucleus, dopamine, norepinephrine, HPLC, microdialysis.
Atıf yapmak için: Solak H, Solak Görmüş IZ, Özen Koca R, Kutlu S. Intravenöz Glikoz Infüzyonu Hipotalamik Ventromediyal Nükleusta Katekolaminleri Etkiler mi?. Selcuk Med J 2021;37(4): 322-327
Açıklama: Yazarların hiçbiri, bu makalede bahsedilen herhangi bir ürün, aygıt veya ilaç ile ilgili maddi çıkar ilişkisine sahip değildir. Araştırma, herhangi bir dış organizasyon tarafından desteklenmedi. Yazarlar çalışmanın birincil verilerine tam erişim izni vermek ve derginin talep ettiği takdirde verileri incelemesine izin vermeyi kabul etmektedirler. 


\section{GíRiş}

Canlıların yaşamlarını sürdürebilmeleri için besin alımı ve metabolik olaylar büyük önem taşır. Besin alımının düzenlenmesi, organizmadaki en karmaşık regülasyon mekanizmalarından birini oluşturmaktadır (1). Vücuda alınacak besin miktarını ve iştahı düzenleyen sinirsel merkezler hipotalamusta bulunur (2). Hipotalamik çekirdekler, enerji dengesini düzenleyen dolaşımdaki peptidlerin ve hormonların uyarısına cevap verir (3). Arkuat çekirdek (ARC), paraventriküler çekirdek (PVN), ventromediyal çekirdek (VMN), lateral hipotalamik alan (LHA) ve dorsomediyal hipotalamus (DMH) dâhil olmak üzere hipotalamus içindeki farklı çekirdeklere nöronal projeksiyonlar gönderir. ARC vücut homeostazının düzenlenmesini sağlar $(4,5)$.

VMN ve ARC'den oluşan ventromediyal hipotalamus $(\mathrm{VMH})$, besin alımının düzenlenmesinde çevresel sinyalleri entegre etmek için önemli bir bölgedir (3). VMN esas olarak tokluk merkezi olarak bilinmektedir (4), glikoz ve enerji homeostazının kontrolünde rol oynamaktadır. VMN'de meydana gelen lezyonlar hiperfajiye, insülin direncine ve obezite sendromlarına yol açar $(6,7)$. VMN ayrıca periferal insülin duyarlılığında ve iskelet kası ve adipoz dokuya glikoz alımında rol oynar. Kan şekeri seviyelerindeki değişiklikleri algılayan ve bunlara yanıt verme yeteneği sağlayan glikoz algılama nöronlarına sahiptir (6,4). 1950'lerde, Jean Mayer'in glukostatik hipotezinde (8), glikoz reseptörlerinin hipotalamusta ve muhtemelen gıda alımının düzenlenmesinde rol oynadığı bilinen diğer merkezi ve çevresel bölgelerde var olduğu bildirilmiştir. Bu hipoteze göre plazma glikoz seviyelerinin beyindeki glikoz reseptörleri tarafından algılandığı ve glikoz kullanımındaki artışın öğün başlamasını tetiklediğini belirtilmiştir (3).

Glikoz sensörleri ilk olarak VMN ve LHA'de keşfedilmiştir (9). VMN ve LHA'daki interstisyel glikoz seviyeleri, kan glikoz konsantrasyonuna göre değişir. VMN glikoz sensörleri, öğünden öğüne gıda alımını düzenler (3). Dopamin (DA) besin alımının düzenlenmesinde, istek ve tatmin duygusunu düzenleyen en önemli nörotransmitterdir (5). DA'nın besin alımına etkisi, yemek yeme için istek duygusunu oluşturmakla ilişkilidir. DA aynı zamanda besinleri temin etmek ve tüketmek için gerekli olan davranışları gösterme ile de bağlantılıdır (10). Beyin sapı çekirdeklerinden çıkan noradrenerjik lifler, hipotalamusu yaygın olarak innerve eder. Hipotalamustaki noradrenarjik liflerde meydana gelen elektriksel ve kimyasal lezyonlar aşırı besin alımına ve obeziteye yol açar (5).

Besin alımının düzenlenmesinde rol oynayan mekanizmaların detaylı olarak ortaya çıkarılması, anoreksiya ve obezite gibi hastalıkların etkin tedavi yöntemlerinin geliştirilebilmesi için önem taşımaktadır. Özellikle hipotalamustaki bazı bölgeler beslenme davranışında önemli rol oynamaktadır. VMN tokluk merkezi, LHA ise açlık merkezi olarak bilinmektedir. LHA'nın elektriksel olarak uyarılması deney hayvanlarında açlık duygusu ve besin alımını indüklerken, VMN'nin uyarılması tokluk duygusu ve beslenmenin sonlandırılmasıyla sonuçlanmaktadır (7). Katekolaminlerin VMN üzerindeki etkilerini konu alan mikrodiyaliz çalışmaları oldukça sınırlı olduğu için bu çalışma planlanmıştır. Besin alımı sırasında VMN'deki norepinefrin (NE) ve DA düzeyinde oluşacak konsantrasyon değişimleri, deney hayvanlarında açlık duygusunu başlatıp sonlandırabileceği bilimsel hipotez olarak kurgulanmıştır. Projenin amacı tok ve aç hayvanlarda intravenöz glikoz infüzyonuyla besin alımının simüle edilerek, VMN'deki katekolamin düzeylerinin uygulama öncesi ve sonrası nasıl değiştiğinin araştırımasıdır. Bu çalışmanın, tokluk merkezinde katekolaminerjik innervasyonun öneminin anlaşılmasına katkı sağlayabileceği düşünülmektedir.

\section{GEREÇLER VE YÖNTEM}

Çalışmadaki deneysel protokoller için 2016040 sayılı etik onay alınmıştır. Deneylerde 350-450 gr ağırlığında 40 adet erişkin Wistar albino erkek sıçan kullanıldı. Hayvanlar 4 gruba ayrıldı. Gruplar, normal beslenen (standart ticari kemirgen yemi: ham protein min. $\% 23$, ham yağ min. $\% 4,5$, lif maks. $\% 6$, kül maks. \%8, ilave mineraller maks. \%2,5)intravenöz (iv) serum fizyolojik (SF) uygulan grup $(n=10)$, normal beslenen- iv glikoz uygulan grup $(n=10)$ ve 24 saat süresince aç bırakılan (sadace su verildi)- iv SF uygulanan grup $(n=10), 24$ saat süresince aç bırakılan- iv glikoz uygulan grup $(n=10)$ şeklinde oluşturuldu. Deney hayvanlarına anestezi için intraperitoneal ketamin (ketamin hidroklorür $50 \mathrm{mg} / \mathrm{ml}$ : Ketalar, Pfizer) $50 \mathrm{mg} / \mathrm{kg}$ olarak verildi. Anestezi derinliği, refleks tepkileri kontrol edildi ve gerektiğinde ek doz anestezik madde verildi. Anestezi sonrası deney hayvanları, sterotaksik cihaza (RWD Life Science CHINA) sabitlendi. Mikrodiyaliz probu (CMA 12, CMA microdialysis, İsveç) vertikal olarak sterotaksik cihazın sağ holderine implante edildi. İşaretlenen bregma noktasının, antero-posterior ve medio-lateral koordinatları belirlendi. Bregma noktası referans alınarak sıçan beyin atlasından elde edilen 
(-1.90 mm) antero-posterior, $(1.80 \mathrm{~mm})$ mediyolateral koordinatlarla sağ ventromediyal çekirdek sağ temporal kemik üzerinde işaretlendi. Mikrodiyaliz probu kılavuz kanül içine yerleştirildi ve $1 \mathrm{~mm}$ 'lik perfüzyon membranlı prob ucunun VMN'ye temas etmesi sağlandı. Rat beyin atlasındaki koordinatlara göre sağ VMN noktasından (koruyucu kanül referans alınırsa $8.2 \mathrm{~mm}$, prob referans alınırsa $9.2 \mathrm{~mm}$ ) vertikal yönde beyin dokusu içine girildi ve sağ VMN'ye ulaşıldı. Mikrodiyaliz işlemi kılavuz kanül ve içine probun yerleştirilmesiyle başladı. Tüm hayvanlardan iv SF ve glikoz uygulamalarından hemen önce ve uygulama sonrası 20. ve 40. dakikalarda birer damla kan alınarak manuel glukometre (Optium Xceed) ile kan glikoz değerleri belirlendi. Mikrodiyaliz işleminin başlamasından 60 dakika sonraki, ilk 20 dakikalık sürede toplanan numuneler, 0 . örnek olarak kabul edildi. İlk 20 dakikalık periyotta toplanan numuneler kontrol grubu olarak kabul edildikten sonra 20. dakikada kuyruk veninden intraketle girilerek glikoz grubuna \%50'lik glikoz çözeltisi (11) ve diğer gruba ise $1,4 \mathrm{ml} / \mathrm{kg}$ dozunda SF infüzyonu yapıldı. Sonraki mikrodiyaliz periyotları da 20'şer dakikalık sürelerde 1. ve 2. (20. dak ve 40. dak.) numuneler toplandı. Yüksek basınçlı sıvı kromatografisi (High performance liquid chromatography-HPLC) sistemine enjekte edilerek katekolamin analizleri yapıldı.

\section{HPLC Sisteminde Katekolamin Analizi}

Katekolamin analizi için Agilent Technologies 1260

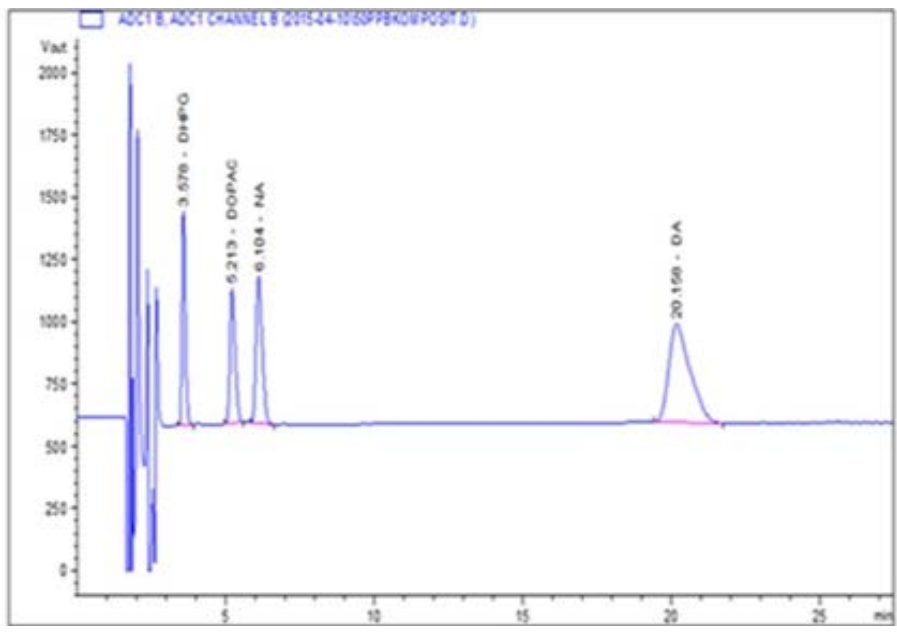

Şekil 1. Standart katekolamin 50 ppb kompozit traseleri. 2-4. dak.arasındaki solvent front, 3.578 dak. DHPG, 5.213 dak. DOPAC, 6.104 dak. NE ve 20.158 dak. DA ait pikler.

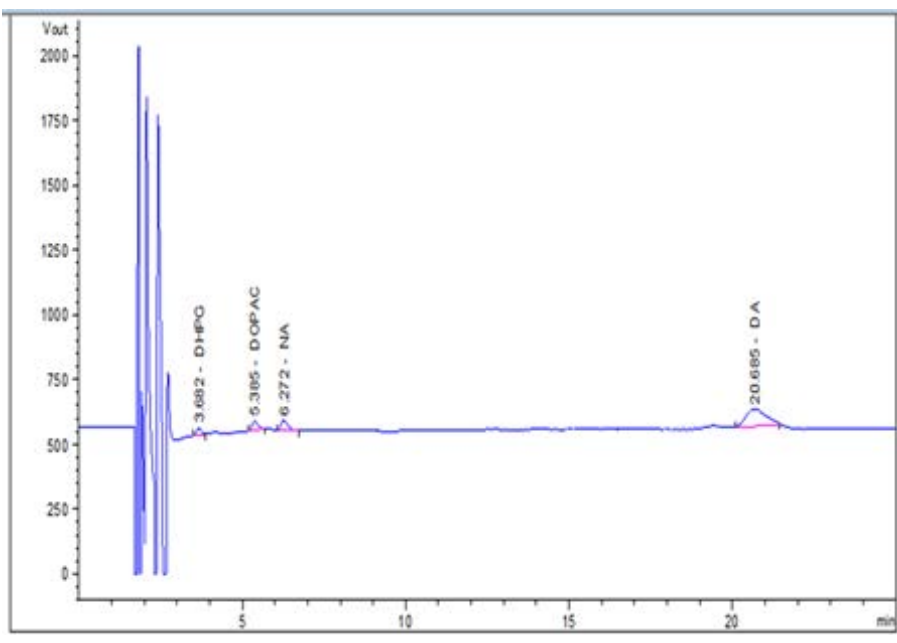

Şekil 2. Mikrodiyaliz sonucu elde edilen numunelerin HPLC'deki katekolamin traseleri.

marka yüksek basınçlı sıvı kromatografisi (HPLC) kullanıldı (250x4,6 mm'lik C18 ODS analitik HPLC kolonu). HPLC analiz aralığı 5 olarak ayarlandı. Kolon fırınının sıcaklığı $40^{\circ} \mathrm{C}$ olarak sabitlendi. HPLC'deki akım hızı $1 \mathrm{ml} / \mathrm{dk}^{\prime} y a$ ayarlandı. Elektrokimyasal dedektör Waters 2465 kullanıldı. Enjeksiyonlar 20 $\mu \mathrm{l}$ (Hamilton) hacimde gerçekleştirildi. Deneylerde mikrodiyaliz örnekleri analiz edilmeden önce, her bir katekolamin için standart eğriler (curve) hazırlandı.

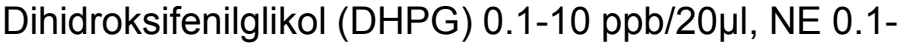
$10 \mathrm{ppb} / 20 \mu \mathrm{l}$, dihidroksifenilasetik asit (DOPAC) 0.1$10 \mathrm{ppb} / 20 \mu \mathrm{l}$, DA 0.1-10 ppb/20 $\mu \mathrm{l}$ arasında 5 farklı doz uygulanarak eğriler çizildi (Şekil 1).

Tüm standartlar için tabloda belirtilen dozlarda uygulamalar yapılarak HPLC'de çıkan alanlar Agilent HPLC software programı ile hesaplandı. Alanları hesaplanan numunelerin $y=90,976 x-16,471$ formülü ile her bir katekolamin için ppb cinsinden konsantrasyonu bulundu. Alan değerleri y değerinin bulunduğu yere yazılarak x konsantrasyon miktarı hesaplandı (Şekil 2).

\section{Istatistiksel Yöntem}

Analizler sırasında SPSS 20.0 paket programı kullanıldı ve değişkenlere ait tanımlayıcı ölçüler Aritmetik Ortalama \pm Standart Hata $(\mathrm{AO} \pm \mathrm{SH})$ şeklinde verildi. Gözlem sayıları az olduğu için normal dağılım kontrolu yapılmadı; analizler için parametrik olmayan yöntemler tercih edildi. Bağımsız iki grup karşılaştırmaları için Mann-Whitney $U$ testi, 
tekrarlı ölçümlü çoklu grupların karşılaştırması için Friedmanın iki yönlü varyans analizi kullanıldı. Analizlerin tamamında $p<0,05$ değeri istatiksel olarak anlamlı kabul edildi.

\section{BULGULAR}

\section{Kan Glikoz Düzeylerin Değerlendirilmesi}

Sıçanların kan glikoz seviyeleri kuyruk venlerinden alınan kandan glukometre ile ölçülerek değerlendirildi. Deney süresince aç ve tok hayvanların kan glikozları hiçbir işlem yapılmadan, uygulamadan önce 0 . dakikada ve glikoz ve SF uygulaması sonucu 20. dakikada ve 40. dakikada ölçülerek karşılaştırıldı. Kan glikoz düzeyleri SF uygulanan grupta değişmezken, glikoz uygulanan grupta artmış olarak bulundu (Tablo 1).

\section{Monoamin Bulguları}

Deneylerden elde dilen mikrodiyaliz numuneleri HPLC'de analizi sonucu hesaplanan 0., 20. ve 40. dakikalardaki mutlak katekolamin değerleri $\mathrm{AO} \pm \mathrm{SH}$ olarak tabloda gösterilmiştir. Aç ve tok hayvanlarda SF ve glikoz uygulanan gruplar

Tablo 1. Normal beslenme şartlarında tutulan tok hayvan ve 24 saat aç bırakılan hayvanlarda kan glikoz değerleri $(\mathrm{AO} \pm \mathrm{SH})$

\begin{tabular}{ll}
\hline Gruplar & AO \pm SH \\
\hline Aç SF AO \pm SH & $65.46 \pm 2.15$ \\
Aç Glikoz AO $\pm S H$ & $181.43 \pm 12.20$ \\
Tok SF AO \pm SH & $121.53 \pm 3.85$ \\
Tok Glikoz AO \pm SH & $221.30 \pm 9.43$ \\
\hline
\end{tabular}

kontrolle karşılaştırıldığında NA ve metaboliti DHPG konsantrasyonları arasında istatiksel bir anlamlılık tesbit edilemedi $(p>0,05)$. DA konsantrasyonları aç hayvanlarda SF uygulanan grupta ve glikoz uygulanan grupta değişmezken, tok ve glikoz uygulanan grupta istatistiksel olarak anlamlı olmayan bir artış gözlendi, ( $p>0,05)$. DA metaboliti olan DOPAC konsantrasyonları ise aç SF ve glikoz uygulanan grupta herhangi bir değişiklik göstermedi, tok glikoz uygulanan grup kontrolle karşılaştırıldığında istatistiksel olarak anlamlı bir artış bulundu $(p<0,05)$, (Tablo 2).

\section{TARTIŞMA}

Hipotalamusun ventromediyal nükleusu, beslenme davranışı, enerji dengesi, cinsel davranış ve kardiyovasküler fonksiyonun düzenlenmesinde rol oynar (12). Yeme davranışının tamamlanmasıyla birlikte ortaya çıkan hiperglisemiVMN'yiaktive ederken beslenme merkezini inhibe ettiği bilinmektedir $(13,3)$. İnsanlarda ve hayvanlarda bu alanın haraplanması ise aşırı kilo alımına ve obeziteye neden olmaktadır (5). Plazma glikoz seviyeleri beyinde bulunan glikoz reseptörleri tarafından algılanır ve glikoz kullanımındaki bir artış besin alımının başlatılmasını tetikler. Glikoz algılayıcıları ilk defa VMN ve LHA'da keşfedilmiştir. Ayrıca VMN ve LHA'da interstisyel glikoz düzeyleri kan glikoz konsantrasyonu ile değişmektedir. Bu bölgeler yoğun şekilde glikoza duyarlı nöronlar içermektedir (14). Mayer et al (15) yaptığı bir in vivo mikrodiyaliz çalışmasında sıçan ventromediyal hipotalamusunda $(\mathrm{VMH})$ beslenme ile

Tablo 2. 24 saat aç bırakılan ve normal beslenen tok hayvan grubunda VMN'deki katekolamin değerleri $(\mathrm{AO} \pm \mathrm{SH})$

\begin{tabular}{|c|c|c|c|c|}
\hline Gruplar & $\begin{array}{l}\text { 0. dak } \\
(\mathrm{AO} \pm \mathrm{SH})\end{array}$ & $\begin{array}{l}\text { 20. dak } \\
(\mathrm{AO} \pm \mathrm{SH})\end{array}$ & $\begin{array}{l}\text { 40. dak } \\
(\mathrm{AO} \pm \mathrm{SH})\end{array}$ & p değeri \\
\hline Aç SF NE & $0,12 \pm 0,02$ & $0,20 \pm 0,55$ & $0,14 \pm 0,03$ & 0,17 \\
\hline Tok SF NE & $0,09 \pm 0,03$ & $0,09 \pm 0,02$ & $0,07 \pm 0,02$ & 0,09 \\
\hline Aç Glikoz NE & $0,20 \pm 0,07$ & $0,14 \pm 0,03$ & $0,12 \pm 0,03$ & 0,79 \\
\hline Tok Glikoz NE & $0,19 \pm 0,03$ & $0,16 \pm 0,05$ & $0,19 \pm 0,04$ & 0,77 \\
\hline Aç SF DHPG & $0,38 \pm 0,07$ & $0,37 \pm 0,12$ & $0,73 \pm 0,35$ & 0,31 \\
\hline Tok SF DHPG & $0,92 \pm 0,18$ & $1,17 \pm 0,42$ & $0,57 \pm 0,09$ & 0,32 \\
\hline Aç Glikoz DHPG & $0,52 \pm 0,08$ & $0,34 \pm 0,05$ & $0,31 \pm 0,05$ & 0,27 \\
\hline Tok Glikoz DHPG & $0,46 \pm 0,09$ & $0,41 \pm 0,07$ & $0,32 \pm 0,07$ & 0,58 \\
\hline Aç SF DA & $0,13 \pm 0,03$ & $0,06 \pm 0,02$ & $0,17 \pm 0,09$ & 0,17 \\
\hline Tok SF DA & $0,46 \pm 0,19$ & $0,34 \pm 0,11$ & $0,30 \pm 0,12$ & 0,32 \\
\hline Aç Glikoz DA & $0,14 \pm 0,03$ & $0,09 \pm 0,03$ & $0,08 \pm 0,01$ & 0,18 \\
\hline Tok Glikoz DA & $0,15 \pm 0,02$ & $0,26 \pm 0,10$ & $0,23 \pm 0,07$ & 0,61 \\
\hline Aç SF DOPAC & $0,21 \pm 0,04$ & $0,19 \pm 0,01$ & $0,23 \pm 0,04$ & 0,93 \\
\hline Tok SF DOPAC & $0,56 \pm 0,17$ & $0,49 \pm 0,14$ & $0,42 \pm 0,13$ & 0,51 \\
\hline Aç Glikoz DOPAC & $0,39 \pm 0,07$ & $0,36 \pm 0,07$ & $0,32 \pm 0,04$ & 0,96 \\
\hline Tok Glikoz DOPAC & $0,62 \pm 0,08$ & $1,49 \pm 0,41^{*}$ & $1,27 \pm 0,41 \#$ & 0,004 \\
\hline
\end{tabular}

Kısaltmalar: DA: Dopamin, DHPG: dihidroksifenilglikol, NE: norepinefrin, SF: serum fizyoloji Mann-Whitney U test, * $(p<0.05), \#(p<0.05)$. 
glikoz konsantrasyonlarındaki değişiklikler arasındaki ilişkiyi araştırılmıştır. Sonuçlar, sıçanlarda VMH glikoz konsantrasyonunun, gıda alımına bağlı olarak önemli ölçüde arttığını göstermiştir. Bu bilgi, çalışmamızda aç hayvanlara besin simülasyonu için glikoz verme sebebimizle uyumludur.

Hipotalamus aracılığıyla enerji dengesini (homeostatik süreçler) düzenleyen nöropeptidler, dopamin hücrelerinin aktivitesini ve bunların gıda alımınında yer alan bölgelere projeksiyonlarını da modüle eder (16). Gálosi R et al (17), katekolamin terminalinde meydana gelen lezyonun vücut ağırlığının azalmasına neden olduğunu bildirmiştir. DA yolaklarında meydana gelen lezyonun gıda yoksunluğundan sonra artan gıda tüketimine neden olduğu tesbit edilmiş, fazla besin alımının, mezolimbik sistemdeki artan DA döngüsünden kaynaklanabileceği belirtilmiştir. $\mathrm{Bu}$ çalışmada tok hayvanlarda glikoz yüklemesi sonucunda VMN'deki DA seviyesinde makroskobik bir artış gözlenirken, DOPAC'ta $(p=0,004)$ istatistiksel olarak anlamlı bir artış olduğu bulunmuştur. Bubulgularglikozinfüzyonun hipotalamik dopaminerjik aktiviteyi artırdığını göstermektedir. $\mathrm{Bu}$ durumda artan dopaminin metabolize olmasıyla DOPAC konsantrasyonunda artış ortaya çıkmıştır. Mikrodiyaliz örnekleri glikoz uygulanmasından sonraki süreçte toplandığı için enzimatik yıkımlanma DA düzeyindeki yükselmeyi muhtemelen baskılamıştır. Sonuçta DOPAC seviyesi daha yüksek olarak analiz edilmiştir.

Hipotalamustaki NE artışının hiperglisemiye, yüksek plazma serbest yağ asidi seviyelerine, iştah artışına ve obeziteye yol açtığı bilinmektedir (18). Dopamin 2 reseptörlerinin (D2R) aktivasyonu NE salgılanmasını azaltır ve bu nedenle DA agonistleri, sempatik sinir sisteminin baskılanması yoluyla metabolizma üzerinde faydalı etkilere sahip olabilir (19). DA salınımının etkisinin, serebral sinyalleri değiştirerek, NE aktivitesini azaltan insülin duyarlılığı gibi metabolik değişiklikleri uyardığı öne sürülmüştür (18). Çalışmamızda NE seviyesindeki değişiklikler istatistiksel olarak anlamlı bulunmamıştır. Bu duruma DA ve metaboliti DOPAC seviyesindeki artışın NE metabolizmasını baskılamasının neden olabileceği düşünülmüştür. İnsanlarda D2R gen mutasyonları ile obezite arasındaki ilişkiyi inceleyen veriler hala sınırlı olsa da, çalışmalar aşırı kilo ile D2R fonksiyon bozukluğu arasındaki bir ilişkiye işaret etmektedir. Obezitenin tersi durumunda, anoreksiya nervozadan muzdarip hastaların striyatal D2R seviyelerinde artış olduğu ve son araştırmalarla anoreksiya nervoza ile çoklu D2R polimorfizmleri arasında bir ilişki olduğu ortaya konulmuştur (20). DA agonistleri ile tedavinin obezite tedavisini iyileştirebileceği öne sürülmüş, kemirgenlerde DA reseptörlerinin striyatal ve hipotalamik aktivitesinin azalmasının, hiperfajiye ve aşırı kilo alımına yol açtığı bildirilmiştir (18). İnsanlarda ve kemirgenlerde yapılan çalışmalar, dopaminerjik sistemin gıda alımını düzenleyen anahtar bir faktör olduğuna işaret etmiş ve aşırı yeme durumu genellikle obezite ve değişen glikoz metabolizması ile ilişkilendirilmiştir $(18,21)$.

Mikrodiyaliz yöntemi uygulanırken deney hayvanlarının derin anestezi altında tutulması gerekmektedir. Çalışmada anestezi için kullanılan ketaminin kan glikoz seviyeleri üzerinde doza bağımlı etki gösterdiği bilinmektedir. Ketamin, düşük ve yüksek dozlarda farklı etkiler oluşturabilir (22). Farklı bir çalışmada ketaminin herhangi bir dozunda klinik olarak kan glikoz seviyesinde anlamlı bir değişiklik olmadığı rapor edilmiştir (23). Çalışma ekibinin daha önce yaptığı çalışmalar ve literatür göz önüne alınarak optimal bir doz uygulanmıştır ve sonucu değiştirecek herhangi bir duruma neden olmadığı düşünülmektedir.

Katekolamin seviyesindeki anlık değişimlerin gözlenebilmesi için mikrodiyaliz çalışmasının en uygun yöntem olduğu düşünülmektedir. Çalışmada mikrodiyaliz metodu bundan dolayı tercih edilmiştir. Çalışmanın kısıtlaması hayvanın mikrodiyaliz süresince sterotaksik cihazda anestezi altında tutulmasıdır. Bu da katekolaminerjik mekanizmalarda değişikliklere sebep olabilmektedir. Fakat gruplara aynı işlemler uygulandığı için hata payı en aza indirilmeye çalışılmıştır. Paraventriküler nukleusta (PVN) NE'nin, sıçanlarda aktif (karanlık) döngünün başlangıcında özellikle karbonhidrat beslenmesini uyarmak üzere etki ettiği öne sürülmüştür. PVN'deki endojen NE seviyeleri ile bu sırada tüketilen gıda miktarı arasındaki ilişki mikrodiyaliz yöntemiyle incelenmiş ve besin alımı sonrasında NE seviyesinde yükselme tesbit edilmiştir (24).

Literatürde aç hayvanlar üzerinde yapılmış olan hipotalamik besin alımı çalışmalarında, sıklıkla norepinefrin bakılmıştır. Mevcut çalışma ise, VMN'de mikrodiyaliz yöntemiyle aç sıçanlara besin alımı yerine simülasyon amaçlı glikoz yüklemesi ve katekolamin olarak DOPAC, Dopamin, DHPG ve NE seviyelerinin araştırılması ile özgün hale gelmiştir. Son yıllarda sunulan kanıtlar, dopaminerjik sistemin glikoz homeostazının kontrolünde önemli bir rol oynadığını öne sürmektedir (19). Çalışmamızda da tok hayvanlarda glikoz yüklemesi sonucunda VMN'de 
DA seviyesinde makroskobik bir artış gözlenirken, DA'nın metaboliti olan DOPAC'taki artış istatistiksel olarak anlamlı bulunmuştur. DOPAC seviyesinin DA miktarından fazla olması DA'nın metabolize olduğunun açık bir göstergesidir. Bu veriler dikkate alındığında, kan glikoz seviyesindeki artışın VMN'deki DA konsantrasyonunu değiştirerek besin alımını düzenleyebileceği sonucunu ortaya çıkarır.

Sonuç olarak; Bu çalışma, hipotalamik VMN'deki dopaminerjik nörotransmisyonun kan glikoz düzeyiyle değişebileceğini göstermektedir. Besin alımını takiben meydana gelen hiperglisemi, VMN'de dopaminerjik nörotransmitter konsantrasyonunu artırarak tokluk duygusunun oluşmasında rol oynayabilir. Böylece dopaminerjik nörotransmisyon aracılı olarak hipotalamik düzeyde besin alımında inhibisyon ortaya çıkabilir.

Çıkar Çatışması: Çalışmada herhangi bir çıkar çatışması yoktur.

Finansal Çıkar Çatışması: Çalışmada herhangi bir finansal çıkar çatışması yoktur.

Yazışma Adresi: Hatice Solak, Necmettin Erbakan Üniversitesi, Meram Tıp Fakültesi, Fizyoloji Anabilim Dalı, Konya, Türkiye E-mail: hhaticesolak@gmail.com

\section{KAYNAKLAR}

1. Valassi E, Scacchi M, Cavagnini F. Neuroendocrine control of food intake. Nutr Metab Cardiovasc Dis 2008;18(2):158-68.

2. Mayer J. Glucostatic mechanism of regulation of food intake. N Engl J Med 1953;249:13-6.

3. Routh $\mathrm{VH}$. Glucose sensing neurons in the ventromedial hypothalamus. Sensors 2010;10:9002-25.

4. Conn MP, Freeman ME. Neuroendocrinology in physiology and medicine. Humana Press Inc 2010;344-49.

5. Meister B. Neurotransmitters in key neurons of the hypothalamus that regulate feeding behavior and body weight. Physiol Behav 2007;10;92(1-2):263-71.

6. Hirschberg PR, Sarkar P, Teegala SB, et al. Ventromedial hypothalamus glucose-inhibited neurones: A role in glucose and energy homeostasis? J Neuroendocrinol 2020;32(1):e12773.

7. Hall JE. Guyton and Hall Textbook of Medical Physiology. In: Gruliow R, ed. Behavioral and motivational mechanisms of the brain-the limbic system and the hypothalamus. USA: Saunders Elsevier 2011:711-20.

8. Mayer J. Regulation of energy intake and the body weight: The glucostatic theory and the lipostatic hypothesis. Ann N Y Acad Sci 1955;15;63(1):15-43.

9. Oomura Y, Kimura K, Ooyama H, et al. Reciprocal activities of the ventromedial and lateral hypothalamic area of cats. Science 1964;31;143:484-85.

10. Meguid MM, Fetissov SO, Varma M, et al. Hypothalamic dopamine and serotonin in the regulation of food intake. Nutrition 2000;16(10):843-57.

11. Sawa T, Okuda C, Harada M, et al. Effects of glucose infusion on cerebral cortical glucose and lactate concentrations during endotoxemia in rats. Anesthesiology 1992;77(4):742-9.

12. McClellan KM, Parker KL, Tobet S. Development of the ventromedial nucleus of the hypothalamus. Front Neuroendocrinol 2006;27(2):193-09.

13. Mayer J, Thomas DW. Regulation of food intake and obesity. Science 1967;21;156:328-37.

14. Song Z, Levin BE, McArdle JJ, et al. Convergence of preand postsynaptic influences on glucosensing neurons in the ventromedial hypothalamic nucleus. Diabetes 2001;50(12):2673-81.

15. Mayer $\mathrm{CH}$, Fink $\mathrm{H}$, Rex $\mathrm{A}$, et al. Changes in extracellular hypothalamic glucose in relation to feding. Eur $\mathrm{J}$ Neurosci 2006;24(6):1695-701.

16. Volkow ND, Wang G, Baler RD. Reward, dopamine and the control of food intake: Implications for obesity. Trends Cogn Sci 2011;15:37-46.

17. Gálosi R, Hajnal A, Petykóa $Z$, et al. The role of catecholamine innervation in the medial prefrontal cortex on the regulation of body weight and food intake. Behav Brain Res 2015;1;286:318-27.

18. Vicchi FL, Luquea GM, Briea B, at al. Dopaminergic drugs in type 2 diabetes and glucose homeostasis. Pharmacol Res 2016;109:74-80.

19. Luo $\mathrm{S}$, Meier $\mathrm{AH}$, Cincotta $\mathrm{AH}$. Bromocriptine reduces obesity, glucose intolerance and extracellular monoamine metabolite levels in the ventromedial hypothalamus of Syrian hamsters. Neuroendocrinology 1998;68(1):1-10.

20. Bergen AW, Yeager M, Welch RA, et al. Association of multiple DRD2 polymorphisms with anorexia nervosa. Neuropsychopharmacology 2005;30(9):1703-10.

21. Johnson PM, Kenny PJ. Dopamine D2 receptors in addictionlike rewarddysfunction and compulsive eating in obese rats. Nat Neurosci 2010;13(5):635-41.

22. Sharif SI, Abouazra HA. Effect of intravenous ketamine administration on blood glucose levels in conscious rabbits. Am J Pharmacol Toxicol 2009;4:38-45.

23. Sahoo AK, Mandall,Kalpana M. Clinical evaluation of effects of intravenous induction agents: Propofol, ketamine and etomidate on blood sugar level. JMSCR 2018;06:363-9.

24. Paez X, Stanley BG, Leibowitz SF. Microdialysis analysis of norepinephrine levels in the paraventricular nucleus in association with food intake at dark onset. Brain Res 1993;19;606(1):167-70. 